\title{
EXPERIMENTAL PERFORMANCE OF SPRAY TYPE HUMIDIFIER IN HUMIDIFICATION-DEHUMIDIFICATION DESALINATION UNIT
}

\author{
M. G. Morsy ${ }^{\text {a }}$, I. M. Ismail ${ }^{a}$ and Ali M. A. Soliman ${ }^{b}$ \\ ${ }^{a}$ Professor of Mechanical Engineering, Faculty of Engineering' Assiut \\ University, Assiut \\ ${ }^{b}$ Instructor, Industrial Technical Institute of Sohag, Sohag
}

(Received May 24, 2009 Accepted September 28, 2009).

A humidification-dehumidification desalination unit was built to study the effect of different operating parameters on the unit performance in the range of inlet water temperature of $33^{\circ}$ to $55^{\circ} \mathrm{C}$.

The productivity of the unit and energy consumption are evaluated under various operating parameters.

It is found that air velocity, inlet water temperature and droplet residence times are the most effective parameters on the unit productivity.

At different operating conditions, the ratio of the energy consumed in the production of condensation or evaporation to the energy input (GOR) and the available energy consumed per unit of condensate or evaporate (SCA) based on condensation rate are strongly depending upon inlet water temperature and air mass flow rate. The unit productivity is approaching $8 \mathrm{~kg} / \mathrm{h}$ of desalinated water at inlet water temperature of $55^{\circ} \mathrm{C}$ which is quite good achievement.

\begin{tabular}{|clcl|}
\hline \multicolumn{3}{|c|}{ NOMENCLATURE } \\
$C$ & Specific heat $(\mathrm{kJ} / \mathrm{kg} \mathrm{K})$ & in & Inlet \\
$C_{v}$ & Nozzle flow coefficient & $\mathrm{m}$ & Mixture \\
$d$ & Nozzle diameter $(\mathrm{m})$ & $\mathrm{n}$ & Nozzle number \\
$h_{f g}$ & Latent heat of vaporization $(\mathrm{kJ} / \mathrm{kg})$ & $\mathrm{o}$ & Outlet \\
$m$ & Mass Flow rate $(\mathrm{kg} / \mathrm{s})$ & $\mathrm{s}$ & Saturated \\
$P$ & Pressure $(\mathrm{Pa})$ & $\mathrm{v}$ & Vapor \\
$T$ & Temperature $\left({ }^{\circ} \mathrm{C}\right)$ & $\mathrm{W}$ & Water \\
$w$ & Humidity ratio of air $\left(\mathrm{kg}{ }_{\mathrm{v}} / \mathrm{kg}_{\mathrm{a}}\right)$ & wb & Wet bulb \\
$x$ & Mass fraction of vapor & Abbreviations \\
Greek & symbols & GOR & Gain output ratio (kJ/ kJ) \\
$\Delta$ & Difference & SCA & Specific consumption of available \\
& & \multicolumn{2}{c}{ energy (kJ/kg) } \\
$\rho$ & Density $\left(\mathrm{kg} / \mathrm{m}^{3}\right)$ & TDS & Total dissolved solids \\
Subscripts & RO & Reverse osmosis \\
a & Air & MED & Multi-effect distillation \\
amb & Ambient air & MSF & Multistage flash \\
cond & Condensate & HD & Humidification-dehumidification \\
e & Evaporation & MEH & Multi-effect humidification- \\
& & & dehumidification \\
\hline
\end{tabular}




\section{INTRODUCTION}

Desalination of sea water is the proper solution for resolving fresh water shortage problem. Over the past decade, the number of desalination plants and total capacity has almost doubled [1]. Taking into account that about $60 \%$ of desalinated water is produced with thermal processes, then the required primary energy on average is about $250 \mathrm{~kJ} / \mathrm{kg}$ of desalted water. That is the value of specific oil consumption is about 3.5 liters of oil per $\mathrm{m}^{3}$ of fresh water produced. Correspondingly, producing the total amount of desalted water of all facilities in the world requires a huge amount of energy. Thus, the present situation demands attention to be diverted to the combined research, design and development of efficient water and energy systems [2]. For large TDS intense aqueous applications such as RO concentrates, waste streams and seawater, other mechanical and thermal technologies economically compete with RO. In the case of seawater desalination, the RO pump pressures increase to 68.95 bar (1,000 psi) and feed waters require expensive pretreatments in order to protect and extend the life of the membranes. The thermally driven plants attempt to reuse the high temperature applied heat as many times as is economically possible to minimize operating costs. The optimum GOR value depends on factors such as plant capacity, cost of energy, cost of materials, interest and tax rates. Applications of conventional desalination and concentration processes are often limited by scaling. Variables that control scaling include: chemical species present, concentration (especially localized pockets of high concentration), temperature, water velocity, residence time and anti scalent additives. These technologies are expensive for small capacity units and can not be used in locations where there are limited maintenance facilities.

In addition, the use of conventional energy sources to drive these technologies has a negative impact on the environment. Remote areas in arid regions, (e.g. areas scattered along the Red Sea and Arabian Gulf in the Middle East) need badly fresh water while enjoying (or suffering) high intensity of solar energy. Effective utilization of this solar energy in producing fresh water from the sea has been the aim of many researches and engineering works in the field of solar desalination. The main efforts in solar desalination were directed to basin solar stills. For the best basin solar stills, the required intercepted solar energy per kg of distillate is equal to several times the latent heat. On the other hand, the heat required for other distillation systems (e.g. MSF or MED systems) represents only a fraction (1/3 to 1/9) of the latent heat. This fact limits the utilization of solar basins to very small capacities. The promising recent development in solar desalination is the use of the HD process. The HD system is based on the fact that air can carry large quantities of water vapor. The vapor carrying capability of air increases with increasing temperature [3]. Generally, this technique presents several advantages such as; flexibility in capacity, moderate installation and operating costs, simplicity, and possibility of usage low temperature energy (geothermal, solar, recovered energy or cogeneration), etc. When compared with the other technologies, it is quite evident that HD can operate over a broad range of feed water salinities, providing a wide window of applicability that could open up many new areas for desalination/concentration, including concentrating the brine from existing reverse osmosis facilities, at the same time providing additional pure water [4]. 
Garg et al. [5] established a 3 liters/day (24 h) capacity experimental HD unit consists of packed tower evaporator with $600 \mathrm{~mm}$ total height, the air stream blown from the bottom occurs through countercurrent contact with a hot brine stream sprayed over the top. They found that rate of production of fresh water increases with increasing temperature of brine, if other parameters like rates of liquid and gas are kept constant. The percentage recovery of fresh water from sea water reached to $2.5 \%$ at $59{ }^{\circ} \mathrm{C}$ brine temperature and brine to air ratio of 2.03 . They found that, the higher the capacity of plant, the lower the cost of investment per thousand gallons and hence the lower the cost of water.

Garga et al. [6] made a design and computer simulation model of a MEH solar desalination, the distillation chamber consists of humidifier (packed type) and dehumidifier towers. The circulation of air in the two towers is being maintained by natural convection. The air humidity ratio at the top of humidifier is calculated, it increases appreciably as the temperature of water at the inlet of the humidifier increases. The rate of distilled water varies linearly as a function of the water temperature at the humidifier inlet.

Yanniotis et al. [7] studied two types of air humidifiers, namely a tubular spray humidifier and a pad humidifier as a part of multiple stage solar desalination process. Experimental results for the evaporation capacity of both humidifiers are compared. At higher air to liquid flow rate ratios, the evaporation rate in the pad humidifier was substantially higher than that is in the spray humidifier. Evaporation rate with counter current flow is greater than that with co-current flow system for the same parameters. When sea water instead of tap water was sprayed in the humidifier, the evaporation rate was slightly lower. This is due to the lower water vapor pressure of the seawater, which results in lower mass transfer driving force for water evaporation.

Hammad et al. [8] designed, simulated, analyzed and optimized a unit to minimize the energy requirements for producing desalinated water using ambient air (humidification-dehumidification process). Air blower supplies air flow rate of $1800-2000 \mathrm{~kg} / \mathrm{h}$ through the backed humidifier. The feed saline water cools saturated air stream leaving the humidifier to produce condensate. Solar energy is used for further heating feed saline water to $70^{\circ} \mathrm{C}$ to enhance the productivity. The production rate is about $1 \mathrm{gpm}$ of desalinated water per $2.25 \mathrm{gpm}$ of saline water.

Hou et al. [9] used pinch technology in the humidification process to determine the maximum possible saturated air temperature and the temperature of water rejected from the unit. The unit consists of two vertical ducts connected by the top and the bottom to form a closed loop for air circulation. The unit is operated in a forced draft mode by using a fan. A large surface condenser is fixed in one of the ducts, while wooden packing is used in the other duct for efficient humidification of air. The study showed that mass flow rate ratio of water to dry air influences thermal energy recovery rate heavily and there exits an optimum mass flow rate ratio of water to dry air for maximum possible saturated air temperature at given temperatures of spraying water and cooling water.

Ismail et al. [10] studied experimentally the performance of laboratory scale HD unit. Productivity is strongly depending upon various operating conditions mainly as inlet water temperature, humidity ratio of ambient air and the ratio of the water to air flow rates. Specific consumption of available energy (SCA) was 
defined and studied with inlet water temperature.

In the previous literatures and other studies [11-14] the humidifiers used were packed types. Many studies were made for spray type humidifier in the cooling applications [15-22]. A few studies were made on spray type humidifier in the desalination applications. In the previous literatures no study has been found that uses nozzles to produce droplets in humidifier in HD techniques. The use of nozzles to produce droplets in spray humidifier means that we have a variable contact area (between air and water) humidifier is obtained with no change in its dimensions. Some new parameters affected the performance like droplets velocity, droplet diameter and nozzles inlet pressure.

In this paper the spray type humidifier (Evaporator) is investigated. Heated water is sprayed from the humidifier top through a set of nozzles against drafted air stream. The water is then circulated to the heating device again. The humidified air then passes through the condenser (Dehumidifier) to obtain fresh water. The performance of the humidifier and the unit was studied.

\section{DATA REDUCTION}

In the following, the main governing equations that were used for unit performance evaluation are given:

Mass flow rate delivered by each nozzle in the humidifier can be determined by:

$$
m_{(n)}=C_{v_{(n)}} \frac{\pi d^{2}}{4} \rho_{w}\left(\frac{2 \Delta P_{w}}{\rho_{w}}\right)^{\frac{1}{2}}
$$

and the total water mass flow rate of nozzles is evaluated from:

$$
m_{w}=\sum_{n=1}^{n} m_{(n)}
$$

The density of air or water vapor can be estimated using the ideal gas equation of state.

Humidity ratio of moist air can be determined in terms of dry and wet bulb temperatures as follows [22]:

$$
w=\frac{\left(2501-2.381 T_{w b}\right) w_{S}-\left(T_{a}-T_{w b}\right)}{2501+1.805 T_{a}-4.186 T_{w b}}
$$

where $w_{s}$ is the humidity ratio of saturated air at temperature $\mathrm{T}_{\mathrm{wb}}$.

The density of moist air is estimated by [23]:

$$
\rho_{m}=\frac{\rho_{a} \rho_{v}}{\rho_{a} X+\rho_{v}(1-x)}
$$

The evaporation rate was calculated as follows:

$$
m_{e}=m_{a}\left(w_{a_{(0)}}-w_{a_{i n}}\right)
$$

where $w_{a_{(0)}}$ is the air humidity ratio at humidifier outlet (top) and $w_{a_{i n}}$ is the air humidity ratio at humidifier inlet (bottom). 
The gain output ratio is defined as the ratio of energy consumed in the condensation or evaporation to the energy input [24]. Based on evaporation rate it is determined from:

$$
G O R_{e}=\frac{m_{e} h_{f g}}{\left[m_{w} C_{p_{w}}\left(T_{w_{(i n)}}-T_{w_{(o)}}\right)+m_{a} C_{p_{a}}\left(T_{a_{(i n)}}-T_{a m b}\right)\right]}
$$

and based on condensation rate it is evaluated from:

$$
G O R_{\text {cond }}=\frac{m_{\text {cond }} h_{f g}}{\left[m_{w} C_{p_{w}}\left(T_{w_{(i n)}}-T_{w_{(o)}}\right)+m_{a} C_{p_{a}}\left(T_{a_{(i n)}}-T_{a m b}\right)\right]}
$$

The specific heat consumption of available energy based on evaporation rate as defined in [10] is evaluated from:

$$
S C A_{e}=\frac{m_{w} C_{w}}{m_{e}}\left[T_{w_{(i n)}}-T_{a m b}-\left(T_{a m b}+273.15\right) \ln \left(\frac{T_{w_{(i n)}}+273.15}{T_{a m b}+273.15}\right)\right]
$$

and based on condensation rate it is evaluated from:

$$
S C A_{\text {cond }}=\frac{m_{w} C_{w}}{m_{c o n d}}\left[T_{w_{(i n)}}-T_{a m b}-\left(T_{a m b}+273.15\right) \ln \left(\frac{T_{w_{(i n)}}+273.15}{T_{a m b}+273.15}\right)\right]
$$

The temperature dependence of densities and specific heats of water and moist air were considered.

\section{EXPERIMENTAL SET UP}

A spray type humidifier in a humidification-dehumidification desalination unit was fabricated. Figure (1) is a schematic diagram and Figure (2) is a photograph of the unit. Eight Tempered glass plates $700 \mathrm{~mm}$ x $800 \mathrm{~mm}$ were assembled with aluminum L angles and fixed with silicon to form $700 \mathrm{~mm}$ x $700 \mathrm{~mm}$ cross sectional area and $1600 \mathrm{~mm}$ height humidifier column.

The column was fixed on a base of the same cross section and $400 \mathrm{~mm}$ height and made of steel sheet of $1.5 \mathrm{~mm}$ thickness. The base has two windows in two sides of $150 \mathrm{~mm}$ height. The humidifier top is made from galvanized steel sheet of $0.5 \mathrm{~mm}$ thickness reduced to $300 \mathrm{~mm} \times 300 \mathrm{~mm}$ duct for air flow. Eliminator plates were set at the top of the humidifier to prevent drift or carry-over of liquid water droplets with leaving moist air. Two air blowers were used, each with capacity about $1000 \mathrm{~m}^{3} / \mathrm{h}$. Each is driven by a $0.375 \mathrm{~kW}$ motor. Each blower was connected to the humidifier base window by galvanized steel duct and was equipped with a gate to control air flow. Twenty three nozzles were designed to produce droplets and they were arranged to provide homogenous distribution of droplets. 


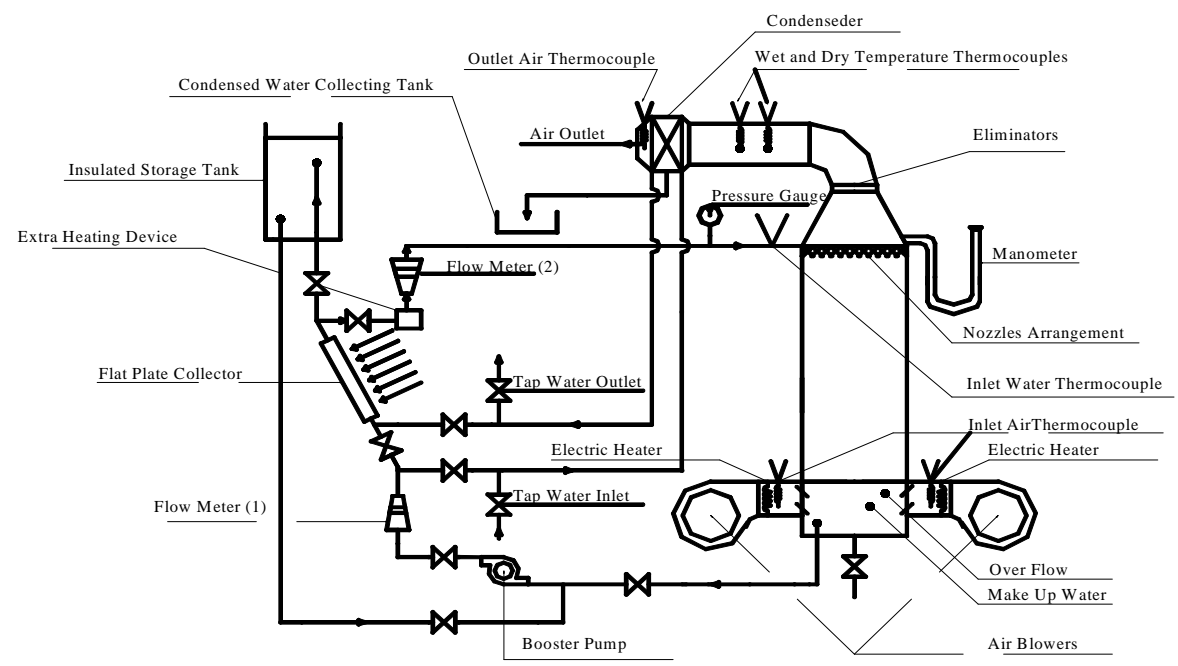

Figure (1) A schematic diagram of HD unit

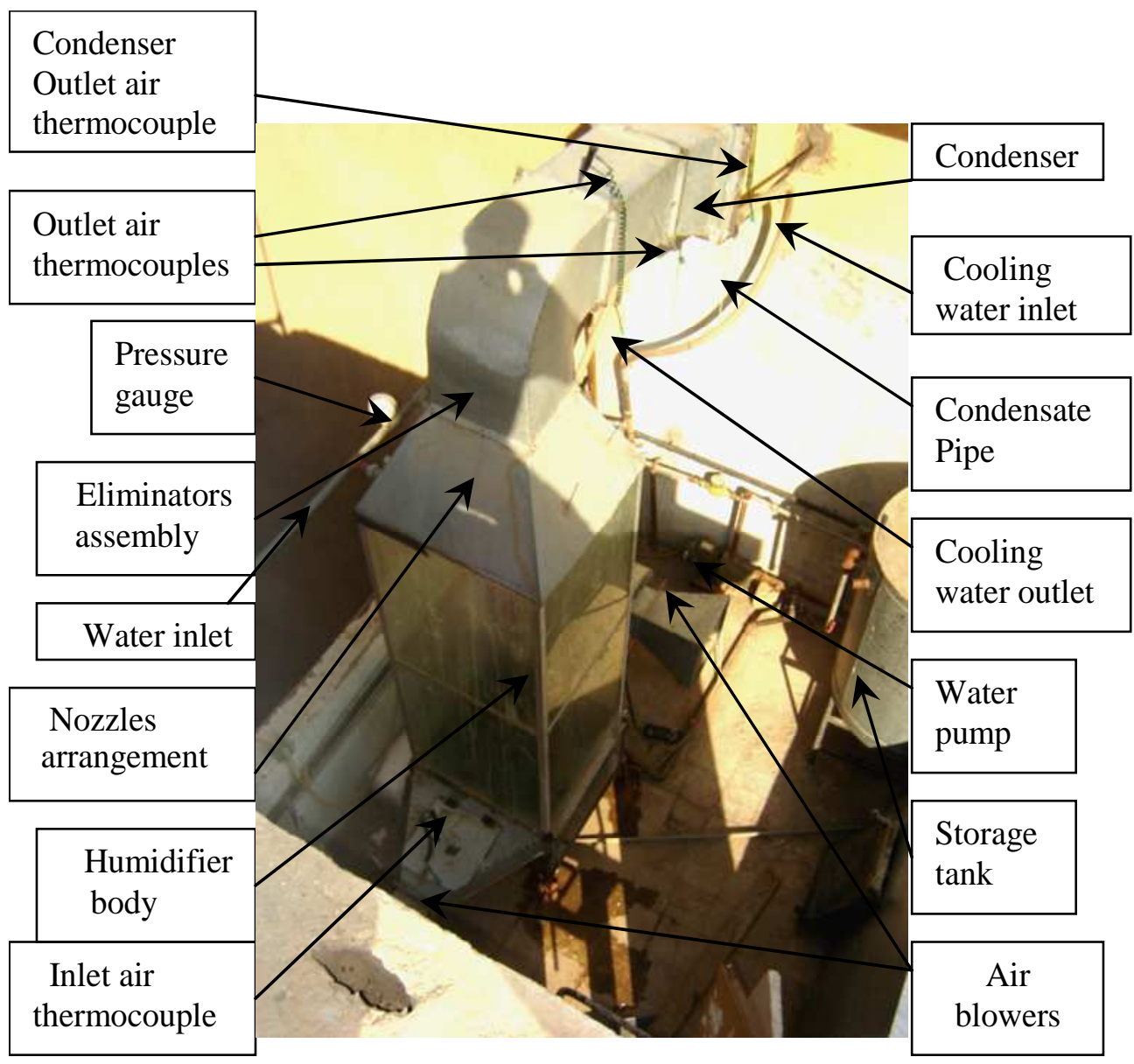

Figure (2) Photograph of HD unit 
The nozzles were calibrated individually by graduated cylinder and stop watch at different pressures ( 0.5 bars, 1.0 bar, and 1.5 bars) and the flow coefficient for each is determined at the specified pressure. Then, the average flow coefficient for each nozzle was determined.

A $0.75 \mathrm{~kW}$ water pump was used to circulate water through the system and to adjust the water pressure entering nozzles. The condenser was chosen from available as a compact heat exchanger which achieves high surface area per unit volume. It was installed and connected to the humidifier exit with a rectangular air duct. Distillate collection tray was connected to the base of condenser and is inclined towards the outlet tube to assure complete discharge of distillate to the measuring graduated cylinder. Two electric heaters $0.5 \mathrm{~kW}$ each were installed at each blower entrance. Other two heaters were installed at blower's outlets $2 \mathrm{~kW}$ each. Thermocouples of type $\mathrm{K}$ were used to measure all temperatures in the system. The temperature indicator has a resolution of $0.1 \mathrm{C}$. The wet bulb temperature was measured by covering the thermocouple junction with water wetted peace of cotton. The velocity of air was measured using a portable digital mini van anemometer model AM-4213. The van anemometer has an accuracy of $\pm(2 \%+0.2)$, a resolution of $0.01 \mathrm{~m} / \mathrm{s}$ and sampling time of $0.8 \mathrm{~s}$.

A flat plate collector was designed and fabricated with 10 copper pipes, $12.5 \mathrm{~mm}$ in diameter and $1950 \mathrm{~mm}$ in length assembled in galvanized steel box of $950 \mathrm{~mm} \times 2000 \mathrm{~mm} \times 100 \mathrm{~mm}$. A $20 \mathrm{~mm}$ thickness foam layer was used as insulation. Stripes of galvanized steel are used around and between pipes as absorber and all (stripes and pipes) were black painted. The collector was covered with $3 \mathrm{~mm}$ glass sheet. An alternative water heater was used to enable adjusting the water temperature. The unit included insulated tank as a storage tank and set of valves to control the flow rates and pressures. A-Bourdon tube pressure gauge having a resolution of 0.1 bar was used to measure the inlet water pressure. Rota meter of type Hidrotek having a resolution of $21 / \mathrm{min}$ was used to measure the water flow rate. The condensate was measured by stop watch and graduated cylinder with $\pm 2 \mathrm{ml}$ accuracy.

To operate the system, the water nozzles inlet pressure is adjusted by the circulating pump and the set of valves. The water flow rate is measured by flow meter (2) and checked with equation (2). The temperature of inlet water then adjusted by the alternative heater. The air mass flow rate is controlled by the air gates. The cooling water flow rate is adjusted by the tap water inlet and outlet valves. The readings were taken where they became constant. The outlet of the humidifier conditions were assumed as those in the inlet to condenser and the effect of eliminators were neglected.

\section{RESULTS AND DISCUSSION}

In the beginning, the flat plate collector was the only means used for water heating. So the temperature of inlet water was low and the condensate was very small and the temperature readings were affected by direct sun light. The alternative heating device was used in absence of direct sun light. 


\section{Effect of Inlet Water Temperature}

The effect of inlet water temperature on the unit performance was investigated at nozzle operating pressure of 0.5 bar and 1 bar fixing the other parameters at the following conditions:

$\begin{array}{ll}\text { Inlet air temperature } & =32.1^{\circ} \mathrm{C} \\ \text { Inlet humidity ratio } & =0.0098 \mathrm{~kg}_{\mathrm{v}} / \mathrm{kg}_{\text {a }} \\ \text { Cooling water flow rate } & =0.27 \mathrm{~kg} / \mathrm{s} \\ \text { Cooling water temperature } & =28.6^{\circ} \mathrm{C} \\ \text { Ambient air temperature } & =21 .{ }^{\circ} \mathrm{C} \\ \text { Air mass flow rate } & =0.11 \mathrm{~kg} / \mathrm{s}\end{array}$

Figure (3) shows the effect of inlet water temperature on the humidifier outlet air humidity ratio. It shows that the humidifier outlet humidity ratio increases as inlet water temperature increases. This is due to the increase of the potential of mass transfer as a result of increasing the vapor pressure of water droplets. At the same time, it is increased due to the increase of contact area (between air and water) as a result of the increase of droplets number and droplets surface area. The latter is a result of the decrease in the viscosity and surface tension of water.

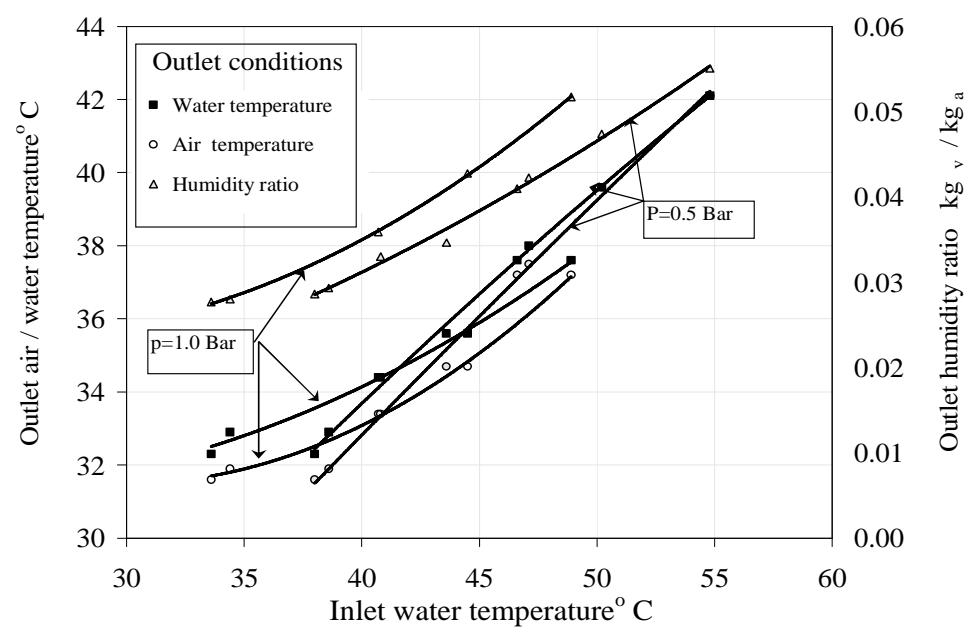

Figure (3) Effect of inlet water temperature on outlet air / water temperatures and humidity ratio

The figure shows also the effect of inlet water temperature on the humidifier outlet air and water temperatures. It is clear that the humidifier outlet air temperature increases as inlet water temperature increases. This is due to the increase of heat transfer by convection. It is obvious that the humidifier outlet water temperature increases as inlet water temperature increases.

Figure (4) shows the effect of inlet water temperature on the unit productivity. It seems that the unit productivity varies linearly with the water temperature at different inlet nozzles pressures. The productivity attains $8 \mathrm{~kg} / \mathrm{h}$ of desalted water at inlet water temperature of $55^{\circ} \mathrm{C}$ which is quite good achievement. It is clear from the figure the large difference between evaporation rate and the condensation rate. This is due to the use of tap water as cooling medium. 


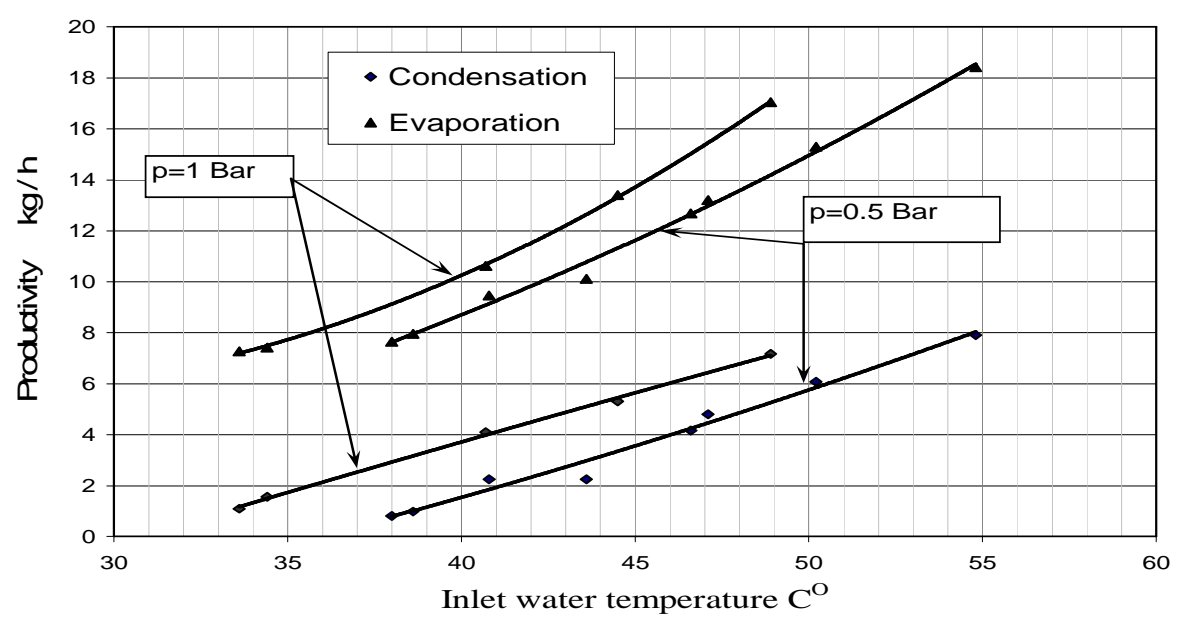

\section{igure (4) Effect of inlet water temperature on unit productivity}

Figure (5) shows the effect of inlet water temperature on the gain output ratio (GOR) based on both condensation and evaporation rates. It shows the big difference between (GOR) based on condensation and that based on evaporation. This is due to the difference between evaporation and condensation rates. This means that the water evaporated in the humidifier was not completely recovered in the condenser. It is clear that, at different nozzles inlet pressures, GOR based on condensation rate increases as inlet water temperature increases and then tends to remain almost constant. This may be explained as follows. As inlet water temperature increases, the mass transfer potential increases then GOR increases. At the same time, the evaporate not recovered in the condenser increases. This decreases GOR.

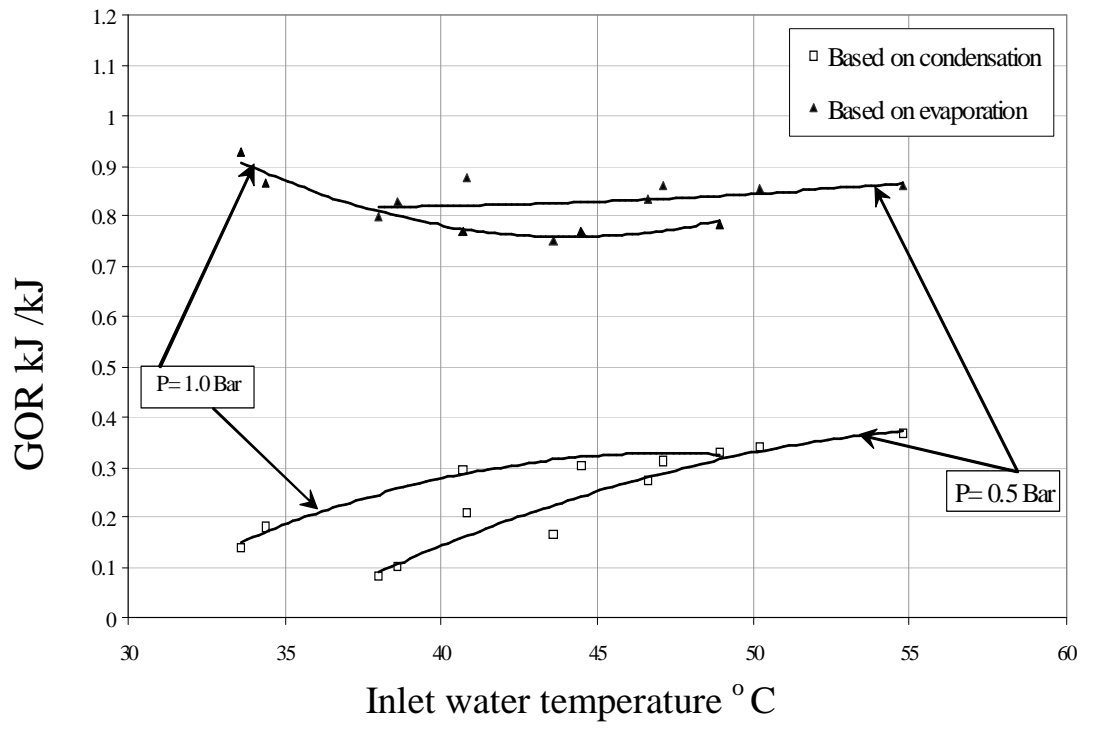

Figure (5) GOR versus inlet water temperature 
Figure (6) shows the effect of inlet water temperature on SCA. It is clear that, at operating nozzles pressure 1 bar, the SCA based on evaporation rate is higher than that at 0.5 bar.

The SCA based on evaporation rate increases as inlet water temperature increases and then tends to remain constant. This can be explained as follows. As the inlet water temperature increases the logarithmic mean temperature difference between system and ambient air increases. This increases the heat loss from the system and consequently increases the SCA. At higher inlet water temperature the mass transfer potential increases. This tends to decrease the SCA. The SCA based on condensation rate decreases as inlet water temperature increases to a minimum and then increases. As inlet water temperature increases the humidifier outlet air humidity ratio and temperature increase. This increases the heat recovered (as desalinated water) in the condenser and SCA decreases. At higher humidifier outlet air temperature the condenser outlet air temperature increases. This means an increase of rejected energy to the ambient air which, in turn, increases SCA.

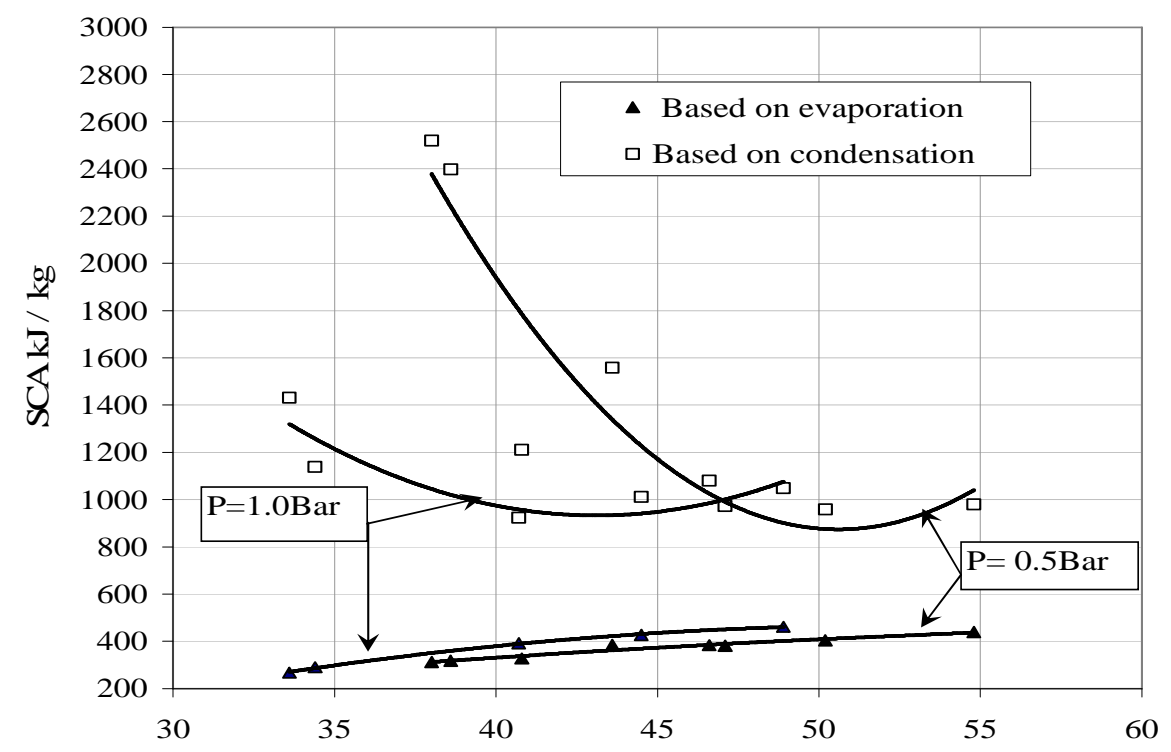

Inlet water temperature $\mathrm{C}^{\mathrm{O}}$

Figure (6) SCA versus inlet water temperature

\section{Effect of Air Mass Flow Rate}

The effect of air mass flow rate on the unit performance is investigated fixing the other parameters at the following conditions:
Inlet water temperature
$=35.5^{\circ} \mathrm{C}$
Inlet air temperature
$=35.0^{\circ} \mathrm{C}$
Inlet humidity ratio
Cooling water flow rate
$=0.012 \mathrm{~kg}_{\mathrm{v}} / \mathrm{kg}_{\mathrm{a}}$
Cooling water temperature
$=0.29 \mathrm{~kg} / \mathrm{s}$
$=26.4{ }^{\circ} \mathrm{C}$ 


$\begin{array}{ll}\text { Inlet water flow rate } & =0.39 \mathrm{~kg} / \mathrm{s} \\ \text { Inlet pressure } & =1.0 \mathrm{bar} \\ \text { Ambient air temperature } & =20.5^{\circ} \mathrm{C}\end{array}$

Figure (7) shows the effect of air mass flow rate on humidifier outlet air humidity ratio. It seems that the humidifier outlet air humidity ratio decreases as air mass flow rate increases. This is due to decreasing of contact time between air and water as air mass flow rate increases.

The figure also shows the effect of air mass flow rate on both humidifier outlet air and water temperatures. It is clear that increasing of air mass flow rate decreases the outlet air temperature. This is due to the decrease in contact time between air and water. It seems also that the outlet water temperature decreases as air mass flow rate increases. This could be explained by the increase in evaporation rate as the air mass flow rate increases. Figure (8) shows the effect of air mass flow rate on the unit productivity. It is clear that the condensation rate increases with air mass flow rate to reach a maximum and then decreases. The evaporation rate increases as air mass flow rate increases. This could be explained as the rate of evaporation resulted in the humidifier is sufficient for specified air mass flow rates to attain the saturation condition. This means that the increase of air mass flow rate within this range causes the increase of the rate of evaporation but the condition of air is unsaturated.

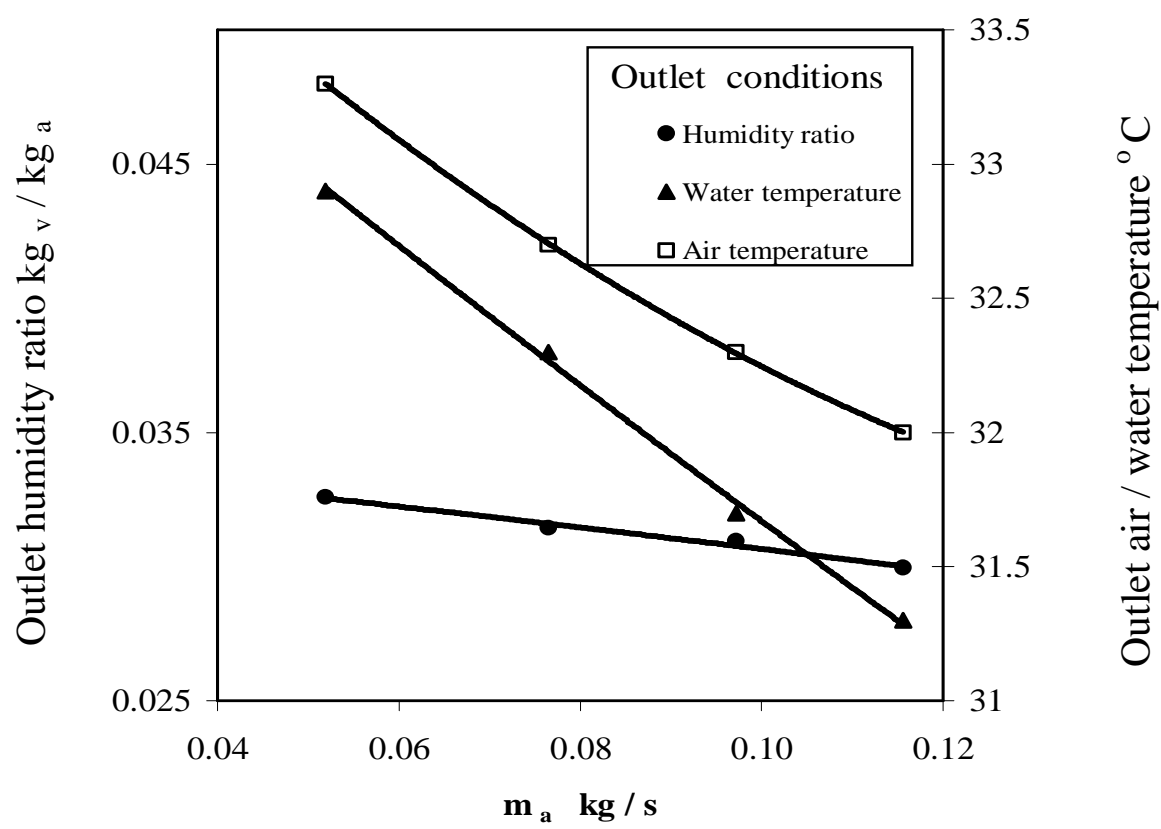

Figure (7) Effect of air mass flow on outlet air / water temperatures and humidity ratio 


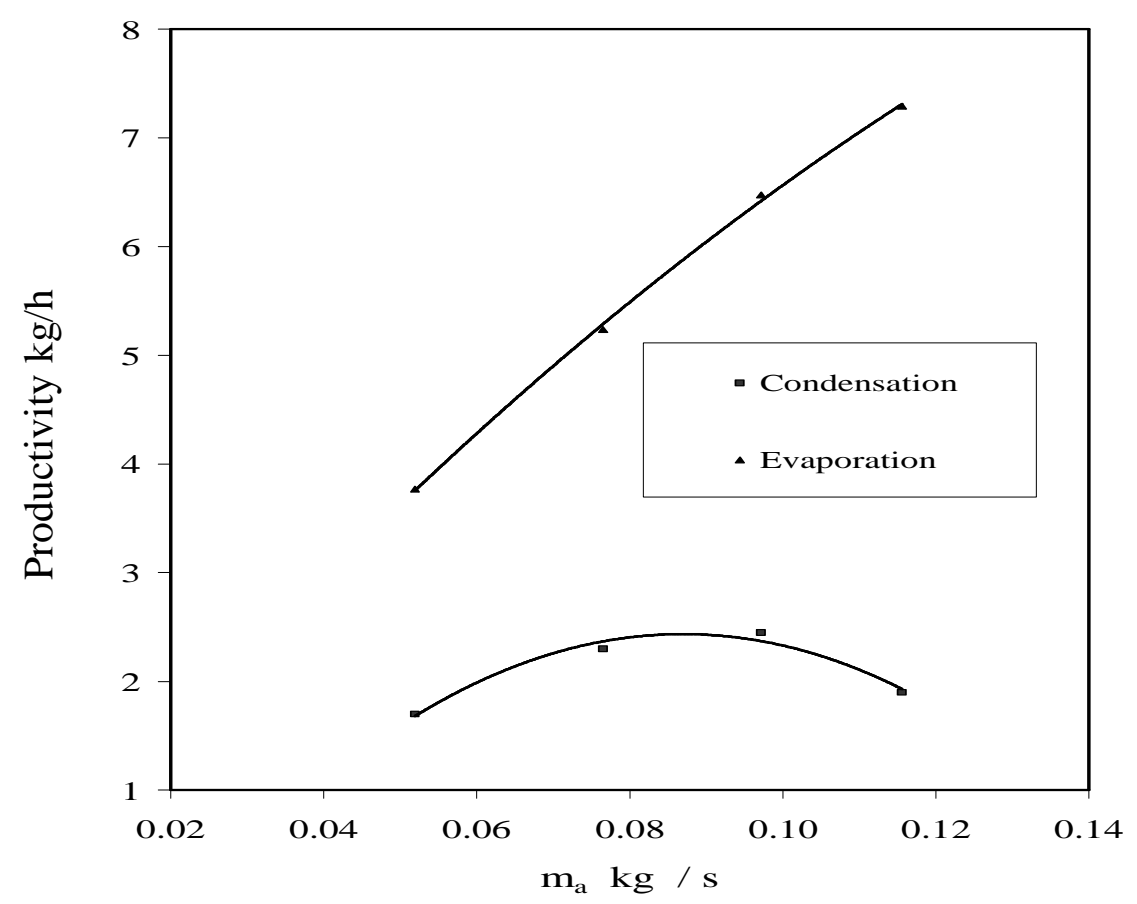

Figure (8) Effect of air mass flow rate on condensation and evaporation rates

Figure (9) represents the effect of air mass flow rate on the GOR. It seems that GOR based on evaporation rate increases as air mass flow rate increases. This is due to the increasing of mass transfer potential and the increasing of vapor removal rate around droplets because of air velocity increase. Also GOR based on condensation rate increases as air mass flow rate increases to a maximum then tends to decrease. This can be attributed to the increase of heat recovered in the condenser (as desalinated water) as humidifier outlet air approaches saturation condition. This increases GOR to reach maximum at saturation condition of air. At unsaturation condition of humidifier outlet air, the heat recovered (as desalinated water) in the condenser decreases then GOR decreases.

\section{CONCLUSIONS}

The productivity increases significantly with the increase of inlet water temperature. A productivity of about $8 \mathrm{~kg} / \mathrm{h}$ of desalinated water was achieved at inlet water temperature of $55^{\circ} \mathrm{C}$ which is quite good. The change of air flow rate affects the unit productivity and there is an optimum value for air mass flow rate for maximum productivity. 


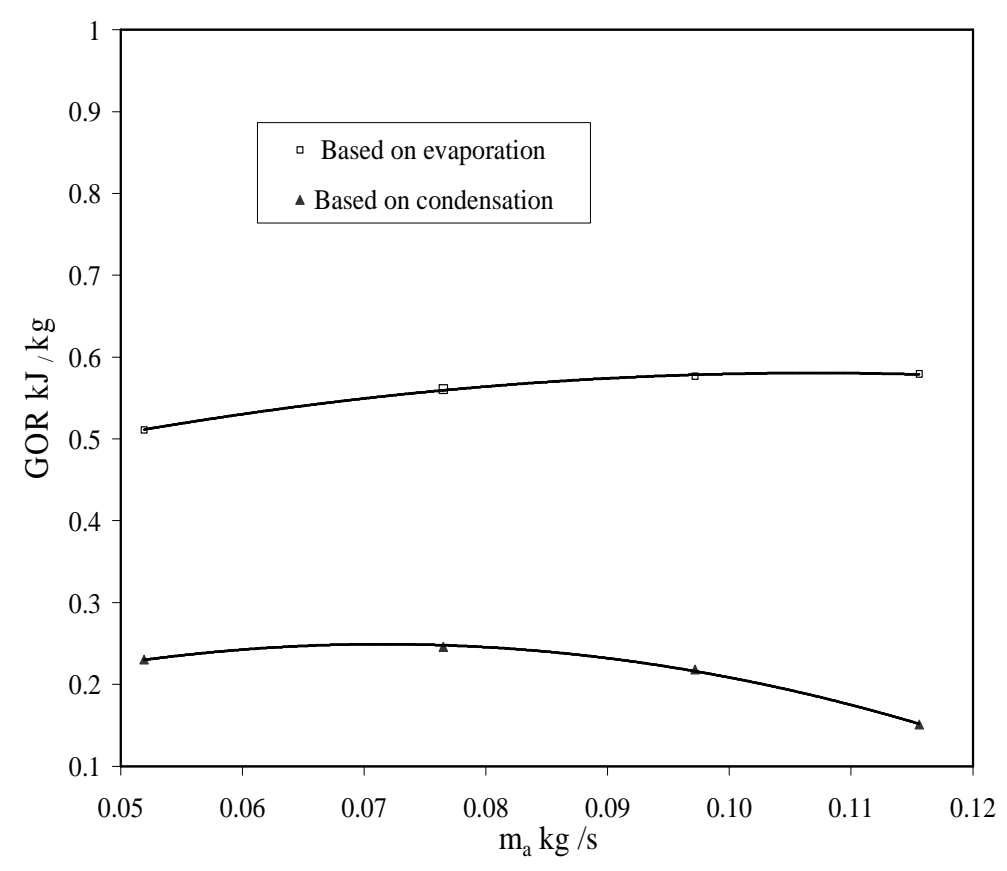

Figure (9) GOR versus air mass flow rate

\section{REFERENCES}

[1] G. Al-Enezi, H. Ettouney and N. Fawzy "Low temperature humidification dehumidification desalination process", J. of Energy Conversion and Management, 47 (2006), 470-484.

[2] J. Uche, "Software for the analysis of water and energy system", J. of Desalination, 156 (2003), 367-378.

[3] A. S. Nafey, "Solar desalination using humidification dehumidification processes", J. of Energy Conversion and Management, 45 (2004), 1263-1277.

[4] R. Larson, "The carrier-gas process-a new desalination and concentration technology", J. of Desalination, 73 (1989), 119-137.

[5] S. K. Garg, S. D. Gomkale, R. L. Datta and D. S. Datar, "Development of humidification -dehumidification technique for water desalination in arid zones in India", J. of Desalination, 5 (1968), 55-63.

[6] H. P. Garga, "Experimental design and computer simulation of multi-effect humidification (MEH)-dehumidification solar distillation", J. of Desalination, 153 (2002), 81-86.

[7] S. Yanniotis, "Air humidification for seawater desalination", J. of Desalination, 158 (2003), 313-319.

[8] A. Hamad and M. Abdul-Karim, "Desalination using ambient air: simulation and energy optimization", J. of Desalination, 175 (2005), 247-257.

[9] S. Houa, "Performance optimization of solar humidification dehumidification desalination process using pinch technology", J. of Desalination, 183 (2005), 143-149. 
[10] I. M. Ismail, "Performance of air humidification dehumidification unit for fresh water production", International Desalination Association, 3 (1999), 159-170.

[11] S. A. Kalogirou, "Design of a new spray-type seawater evaporator", J. of Desalination, 139 (2001), 345-352.

[12] R. L. Datta, S. D. Comieale, S. Y. Aiwed and D. S. Datar, "Evaporation of sea water in solar still and its development for desalination", Proceedings First International Symposium on Water Desalination, Washington, 2 (1967), 1930.

[13] E. Chafik , "A new seawater desalination process using solar energy", J. of Desalination, 153 (2002), 25-37.

[14] M. M. Alhazmy, "Minimum work required for water production in humidification dehumidification desalination cycle", J. of Desalination, 214 (2007), 102-111.

[15] A. S. Kaiser, M. Lucas , A. Viedma and B. Zamora, "Numerical model of evaporative cooling processes in a new type of cooling tower", J. of Heat and Mass Transfer, 48 (2005), 986-999.

[16] A. R. Elgalban, "Numerical simulation of adiabatic evaporative cooler", $12^{\text {th }}$ International Mechanical Power Engineering Conference, 3 (2001), 27-42.

[17] J. C. BECK and A. P. Watkins, "On the development of spray sub models based on droplet size moments", J. of Computational Physics, 182 (2002), 586-621.

[18] K. A. Estes and I. Mudawar, "Correlation of Sauter mean diameter and critical heat flux for spray cooling of small surfaces", J. of Heat Mass Transfer, 38 (1995), 2985-2996.

[19] S. P. Fisenko, A.A. Brin and A.I. Petruchik, "Evaporation cooling of water in a mechanical draft cooling tower", J. of Heat and Mass Transfer, 47 (2004), 165-177.

[20] G. Brenn, (On the controlled production of sprays with discrete polydisperse drop size spectra,"J. of Chemical Engineering Science, 55 (2000), 5437-5444.

[21]S. S. Kachhwaha, "Experimental studies and numerical simulation of evaporative cooling of air with a water spray", J. of Heat and Mass Transfer, 41 (1998), 447-464.

[22] A. K. M. Mohiuddin and K. Kant, "Knowledge base for the systematic design of wet cooling towers. Part I: Selection and tower characteristics", J. of Refrigeration, 19 (1996), 43-51.

[23] M. K. Abu Arabi and K. V. Reddy, "Performance evaluation of desalination processes based on the humidification-dehumidification cycle with different carrier gases", J. of Desalination, 156 (2003), 281-293.

[24] S. Parekh, M. M. Farid, J. R. Selman and S. AL-Hallaj, "Solar desalination with a humidification-dehumidification technique -a comprehensive technical review", J. of Desalination, 160 (2004), 167-186. 


\section{دراسة عملية لأداء وحدة تحلية مياه تعمل بمبدأ ترطيب و إعادة فصل الرطوية من الهواء}

تم تصميم وإنشاء وحدة تحلية تعمل بمبدأ الترطيب و إعادة فصل الرطوبة من الهواء. وتتكون هذه الوحدة من المرطب من النوع الخالي من الحشو، ويقوم علي رش المياه علي ولي هيئة قطرات من اعلي المرطب عن طريق استخدام مجموعة من الفواني المصنعة محليا، والتي اختبرت

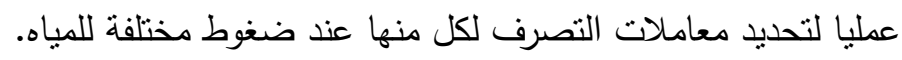
كما استخدم مكثف لإعادة تكثيف بخار المساء باستخدام مكثف ذو مسـاحة سطح عاليـة لانتقال

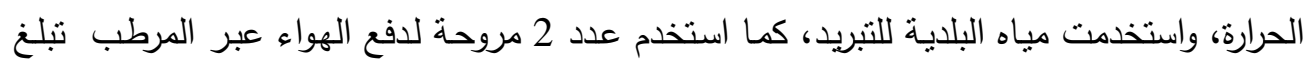
قدرة كل منهما 0.375 كيلوات، واستخدم في تدوير المياه من الخزان السفلي ودفع المياه عبر الفواني طلمبة طاردة مركزية قدرتها 0.75 كيلوات.

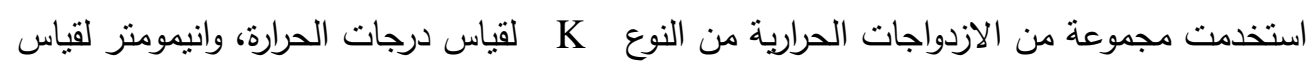

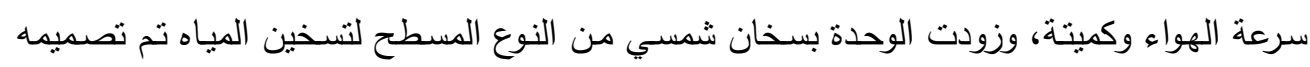
وتصنيعه محليا، هذا بالإضافة إلى وحدة تسخين غاز إضافية للتحكم في درجات الحرارة للمباه.

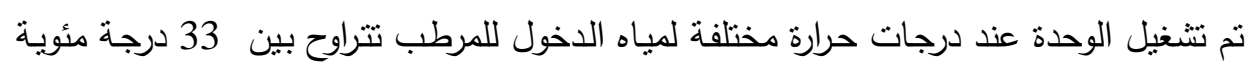

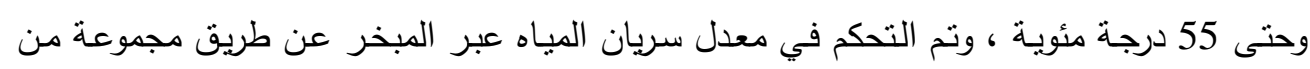
المحابس.

وقد بلغت إنتاجية الوحدة من المياه المقطرة خلال المكثف 8 لتر / ساعة وهو ما يعد نتيجة مرضية ومشجعة. وقد ظهر جليا نأثير درجة حرارة المياه عند الدخول للمرطب علي إنتاجية الوحدة، والذي يعد الأكبر تأثنيرا من بين المتغيرات كافة.

وقد أظهرت النتائج انه يوجد قيمة مثلي لمعدل سريان الهواء خلال الوحدة يحقق اكبر إنتاجية.

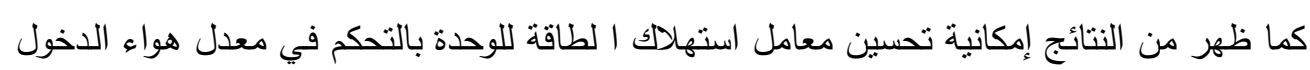
ودرجة حرارة المياه عند الدخول.

الخلاصـة:تنثنل هذه الوحدات مـن طرق التحليـة ذات السـعات الصـيرة والتـي تتميز بسـهولة تصنيعها وتتغيلها ، وتحتاج إلي دراسات أخري لتحسين أداء مكوناتها لرفع إنتاجية الوحدة. 